\title{
Penerapan Line Balancing Pada Lintasan Sewing Proses Produksi Apparel Perusahaan Garmen Puspa Dhewi Batik
}

\author{
Mukhtar Anggit $\mathbf{N}^{* 1)}$, Lobes Herdiman²) \\ 1) Assistant Product Planning and Design Laboratory Program Studi Teknik Industri Universitas Sebelas Maret Jl. Ir. \\ Sutami, 36 A, Surakarta, Indonesia \\ 2) Product Planning and Design Laboratory Program Studi Teknik Industri Universitas Sebelas Maret Jl. Ir. Sutami, 36
} A, Surakarta, Indonesia

DOI: 10.20961/performa.18.2.26318

\begin{abstract}
Abstrak
Perusahaan Garmen Puspa Dhewi Batik bergerak di bidang industri garmen yang memproduksi secara make to order. Tujuan dari penelitian ini adalah untuk meningkatkan efisiensi keseimbangan lini produksi pada lintasan sewing. Lintasan sewing dipilih sebagai objek penelitian karena lintasan tersebut memiliki waktu proses yang paling lama. Dalam upaya peningkatan efisiensi tersebut digunakan metode line balancing berdasarkan perhitungan Standard Minute Value dengan memperhatikan pitch time, under control limit, dan upper control limit. Perhitungan line balancing dilakukan untuk meningkatkan efisiensi keseimbangan lintasan sewing dengan melakukan perubahan pada elemen kerja berdasarkan pitch time. Melalui metode ini didapatkan balance efficiency sebesar 85\% pada lintasan sewing. Perubahan juga terjadi pada elemen kerja yang terdiri dari 23 elemen kerja menjadi 21 elemen kerja. Setelah perhitungan line balancing didapatkan rata-rata hasil produksi pada lintasan sewing setiap jamnya sebesar 61 pcs dan setiap harinya sebesar 495 pcs.
\end{abstract}

Kata kunci: Line balancing, efisiensi, sewing

\begin{abstract}
Puspa Dhewi Batik Garment Company engages in the garment industry which produces make to order. The purpose of this study is to improve the balance efficiency of the production line in the sewing line. Sewing line was chosen as an object, because the line has the longest processing time. In order to increase the efficiency, line balancing method is used based on the calculation of Standard Minute Value, pitch time, under control limit, and upper control limit. The line balancing calculation is to determine the balance efficiency of the sewing line by making changes to the work element based on pitch time. Through this method, the balance efficiency is $85 \%$ in the sewing line. There are work elements changed of 23 work elements into 21 work elements. After the calculation of line balancing, the average in sewing line every hour is 61 pcs and every day is 495 pcs.
\end{abstract}

Keywords: Line balancing, efficiency, sewing

\section{Pendahuluan}

Industri garmen merupakan sektor industry terbesar ke 3 di Indonesia dan menjadi salah satu penyerap tenaga kerja terbanyak. Indonesia memiliki potensi besar dalam industry tekstil sejak tahun 1980 namun mengalami kesulian dalam hal produktivitas dan turnover tenaga kerja (Daryanto, 2012). Produktivitas tenaga kerja harus diperhatikan oleh perusahaan karena berpengaruh terhadap kualitas dan kuantitas produk yang dihasilkan. Produktivitas tenaga kerja dipengaruhi oleh sistem produksi yang digunakan karena sistem produksi berkaitan dengan aktivitas dalam menghasilkan output dengan teknik produksi tertentu untuk memproses input sedemikian rupa (Sukirno, 2002). Salah satu faktor yang dapat meningkatkan produktivitas pada sistem produksi adalah keseimbangan lini produksi (line balancing). Line balancing merupakan penyeimbangan penugasan elemen-elemen tugas dari suatu assembly line ke work station untuk meminimumkan total harga idle time (Gaspersz, 2004).

Garment Puspa Dhewi Batik merupakan perusahaan yang memproduksi secara make to order. Barang yang diproduksi pada perusahaan garmen Puspa Dhewi Batik berupa kemeja, dress, dan celana. Penelitian ini dilakukan pada produk celana kulot dusty basic, hal tersebut dikarenakan banyaknya hasil dari proses sewing yang mengalami rework sehingga menyebabkan waktu proses pengerjaan pada lintasan sewing terlalu lama. Berdasarkan permasalahan diatas, penelitian ini dibuat dengan tujuan untuk meningkatkan efisiensi

\footnotetext{
${ }^{*}$ Korespondensi : mukhtaranggit@gmail.com
} 
keseimbangan lintasan sewing Penelitian sebelumnya dilakukan oleh Nunung Nurhasanah pada perusahaan PD Sandang Jaya tahun 2019. Perbedaan antara penelitian ini dengan sebelumnya adalah objek penelitian serta penggunaan SMV untuk perhitungan line balancing.

\section{Metode Penelitian}

Metode penelitian dilakukan dengan observasi secara langsung yang bertujuan untuk mengetahui proses produksi dan masalah yang ada pada lintasan produksi. Setelah diketahui masalah yang ada pada lintasan produksi, kemudian mencari studi literatur mengenai masalah tersebut. Kemudian, dilakukan identifikasi masalah pada lintasan produksi yaitu banyaknya bottleneck yang terjadi pada lintasan sewing yang menyebabkan aliran proses produksi tidak berjalan dengan lancar sehingga output yang dihasilkan tidak sesuai dengan target. Langkah selanjutnya yaitu melakukan pengumpulan data mengenai waktu yang dibutuhkan untuk memproduksi celana kulot dusty basic. Dari data yang telah diperoleh, dilakukan pengolahan data dengan tahapan penentuan bottleneck pada proses produksi, penentuan penyebab terjadinya bottleneck pada lintasan sewing, perhitungan keseimbangan lini produksi awal pada lintasan sewing, perhitungan lini produksi usulan pada lintasan sewing, dan perbandingan lini produksi awal dan usulan pada lintasan sewing. Setelah itu dilakukan analisis dan interpretasi hasil dengan tahapan penentuan penyebab bottleneck pada proses produksi, penentuan penyebab terjadinya bottleneck pada lintasan sewing, perhitungan keseimbangan lini produksi awal pada lintasan sewing, perhitungan lini produksi usulan pada lintasan sewing, dan perbandingan lini produksi awal dan usulan pada lintasan sewing. Setelah dilakukan analisis mengenai permasalahan dan usulan perbaikannya kemudian dibuat kesimpulan dan saran mengenai penelitian yang telah dilakukan.

\section{Hasil dan Pembahasan}

Sistem produksi yang dilakukan pada proses produksi celana kulot dusty basic terdiri dari input proses output. Input yang digunakan yaitu kain, interlining, tali, dan karet. Input tersebut diolah memalui proses cutting, cutting, sewing, QC sewing, cleaning, ironing, QC, dan packaging. Setelah melalui proses tersebut dihasilkan output berupa celana kulot dusty basic yang sesuai dengan PPS (Pre Production Sample). Akan tetapi, terdapat beberapa permasalahan pada saat melakukn proses produksi, yaitu aliran lintasan produksi yang tidak berjalan dengan lancar sehingga mengalami bottleneck yang menyebabkan kualitas dan kuantitas produk tidak sesuai dengan pesanan customer. Untuk mengetahui penyebab dari bottleneck tersebut dilakukan perhitungan waktu proses produksi sebagai tabel 1 .

Tabel 1. Waktu Proses Produksi

\begin{tabular}{|c|c|c|c|c|}
\hline Proses & Elemen Kerja & $\begin{array}{l}\text { Waktu } \\
\text { Proses }\end{array}$ & $\begin{array}{c}\text { Waktu } \\
\text { Persiapan }\end{array}$ & $\begin{array}{c}\text { Waktu } \\
\text { Menganggu }\end{array}$ \\
\hline \multirow{8}{*}{ CUTTING } & Gelar kain & \multirow{8}{*}{1,385} & \multirow{8}{*}{0,964} & \multirow{8}{*}{18,496} \\
\hline & Gelar kertas pola & & & \\
\hline & Potong & & & \\
\hline & Press interlining & & & \\
\hline & \begin{tabular}{|l|} 
Pengikatan kain \\
\end{tabular} & & & \\
\hline & Numbering & & & \\
\hline & Pengikatan kain & & & \\
\hline & Numbering & & & \\
\hline & Loading & & & \\
\hline & Menjahit Paspol & & & \\
\hline & Unloading & & & \\
\hline & Loading & & & \\
\hline & Menjahit Saku & & & \\
\hline & Unloading & & & \\
\hline & Loading & & & \\
\hline & Menjahit Tali & & & \\
\hline & Unloading & & & \\
\hline & Loading & & & \\
\hline & Menjahit karet pada waistban & & & \\
\hline & Unloading & & & \\
\hline & Loading & & & \\
\hline & Menjahit waistban pada celana & & & \\
\hline & Unloading & & & \\
\hline & Loading & & & \\
\hline & Menjahit celana bagian dalam & & & \\
\hline & Unloading & & & \\
\hline & Loading & & & \\
\hline & Menjahit celana bagian luar & & & \\
\hline
\end{tabular}


Tabel 1. Waktu Proses Produksi (Lanjutan)

\begin{tabular}{|c|c|c|c|c|}
\hline Proses & Elemen Kerja & $\begin{array}{l}\text { Waktu } \\
\text { Proses }\end{array}$ & $\begin{array}{c}\text { Waktu } \\
\text { Persiapan }\end{array}$ & $\begin{array}{c}\text { Waktu } \\
\text { Menganggu }\end{array}$ \\
\hline \multirow{49}{*}{ SEWING } & Unloading & \multirow{49}{*}{14,286} & \multirow{49}{*}{6,559} & \multirow{49}{*}{0,000} \\
\hline & Loading & & & \\
\hline & Menjahit lipatan bagian depan celana & & & \\
\hline & Unloading & & & \\
\hline & Loading & & & \\
\hline & Menjahit heming bawah & & & \\
\hline & Unloading & & & \\
\hline & Loading & & & \\
\hline & Menjahit belahan bawah & & & \\
\hline & Unloading & & & \\
\hline & Loading & & & \\
\hline & Menjahit label & & & \\
\hline & Unloading & & & \\
\hline & Loading & & & \\
\hline & Mengobras Paspol & & & \\
\hline & Unloading & & & \\
\hline & Loading & & & \\
\hline & Mengobras Saku & & & \\
\hline & Unloading & & & \\
\hline & Loading & & & \\
\hline & Mengobras Tali & & & \\
\hline & Unloading & & & \\
\hline & Loading & & & \\
\hline & Mengobras waistban & & & \\
\hline & Unloading & & & \\
\hline & Loading & & & \\
\hline & Mengobras celana bagian dalam & & & \\
\hline & Unloading & & & \\
\hline & Loading & & & \\
\hline & Mengobras celana bagian luar & & & \\
\hline & Unloading & & & \\
\hline & Loading & & & \\
\hline & Mengobras heming bawah & & & \\
\hline & Unloading & & & \\
\hline & Loading & & & \\
\hline & Assembly paspol dengan celana & & & \\
\hline & Unloading & & & \\
\hline & Loading & & & \\
\hline & Assembly saku dengan celana & & & \\
\hline & Unloading & & & \\
\hline & Loading & & & \\
\hline & Assembly celana bagian kanan dan kiri & & & \\
\hline & Unloading & & & \\
\hline & Loading & & & \\
\hline & Assembly tali dengan waistban & & & \\
\hline & Unloading & & & \\
\hline & Loading & & & \\
\hline & assembly waistban dengan celana & & & \\
\hline & Unloading & & & \\
\hline QCSEWING & Memerikasa hasil jahit & 4,272 & 0,831 & 15,742 \\
\hline CLEANING & Memeriksa dan cutting benang sisa & 3,133 & 0,381 & 17,331 \\
\hline \multirow{4}{*}{ IRONING } & Menyetrika ban depan & \multirow{4}{*}{11,751} & \multirow{4}{*}{0,825} & \multirow{4}{*}{8,269} \\
\hline & menyetrika ban belakang & & & \\
\hline & menyetrika bagian depan & & & \\
\hline & menyetrika bagian belakang & & & \\
\hline$Q C$ & Memeriksa tidak terjadi cacat & 1,748 & 0,761 & 18,336 \\
\hline \multirow{2}{*}{ PACKAGING } & Melipat & \multirow{2}{*}{1,575} & \multirow{2}{*}{0,239} & \multirow{2}{*}{19,031} \\
\hline & Memasukan ke dalam plastik OPP & & & \\
\hline
\end{tabular}

Waktu proses produksi dihitung dengan melakukan pengamatan sebanyak 3 kali untuk mengetahui rata-rata waktu yang dibutuhkan setiap elemen kerja. Pengamatan tersebut dilakukan secara langsung dengan menggunakan stopwatch. Berdasarkan pengamatan waktu tersebut dapat ditentukan waktu proses, waktu persiapan, waktu menganggur, dan waktu menunggu. Waktu proses paling lama dilakukan pada stasiun kerja sewing sebesar 14,286 menit. waktu persiapan paling lama dilakukan pada stasiun kerja sewing sebesar 6,559 menit, dan waktu menganggur paling lama dilakukan pada stasiun kerja packaging sebesar 19,031 menit. Data tersebut diperjelas dengan menggunakan grafik pada gambar 2.

Pada gambar 2, setiap stasiun kerja memiliki waktu persiapan, waktu proses, dan waktu menganggur yang berbeda-beda. Stasiun kerja sewing memiliki waktu proses dan waktu persiapan yang paling lama dibandingkan dengan stasiun lainnya. Hal tersebut mengakibatkan aliran lintasan produksi tidak berjalan dengan lancar dan menimbulkan terjadinya bottleneck pada lintasan tersebut. Oleh karena itu, penelitian dilakukan pada stasiun kerja sewing untuk mengatasi bottleneck yang terjadi dan mengetahui efisiensi keseimbangan lintasan sewing. 


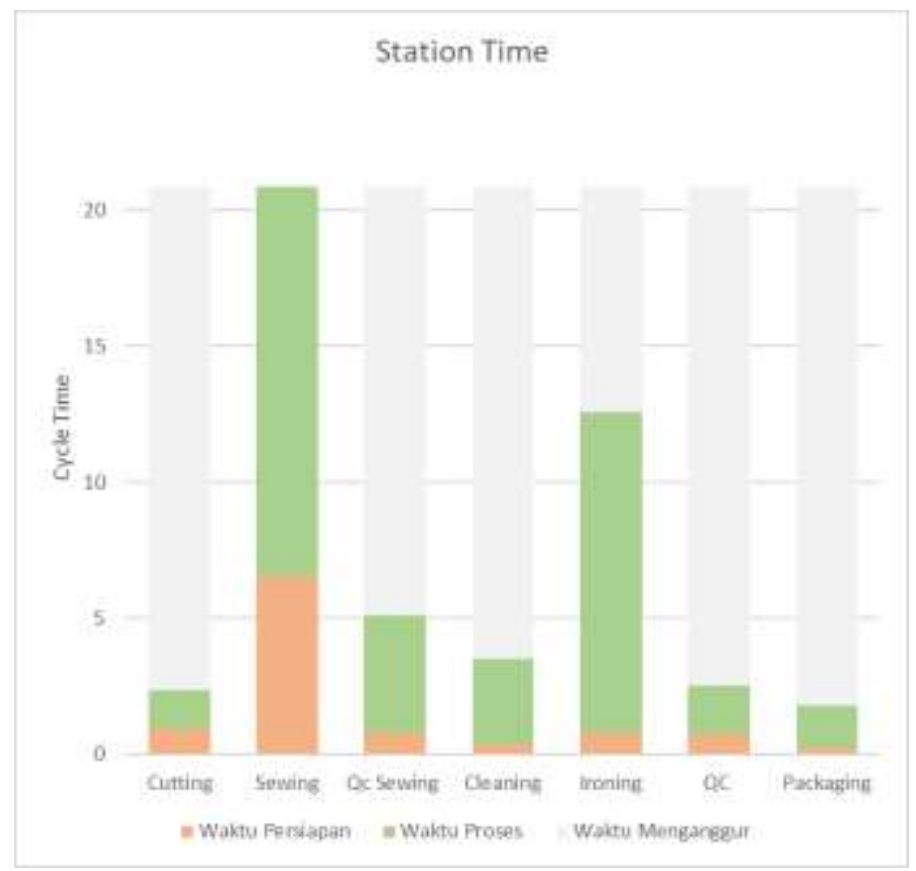

Gambar 2. Grafik Waktu Proses Produksi

Bottleneck yang terjadi pada lintasan sewing dapat diketahui penyebabnya dengan melakukan identifikasi pada beberapa faktor yang ada pada lintasan produksi yaitu faktor lingkungan, metode yang digunakan, material, manusia, dan mesin. Faktor-faktor tersebut dapat digambarkan dengan fishbone diagram sebagai berikut :

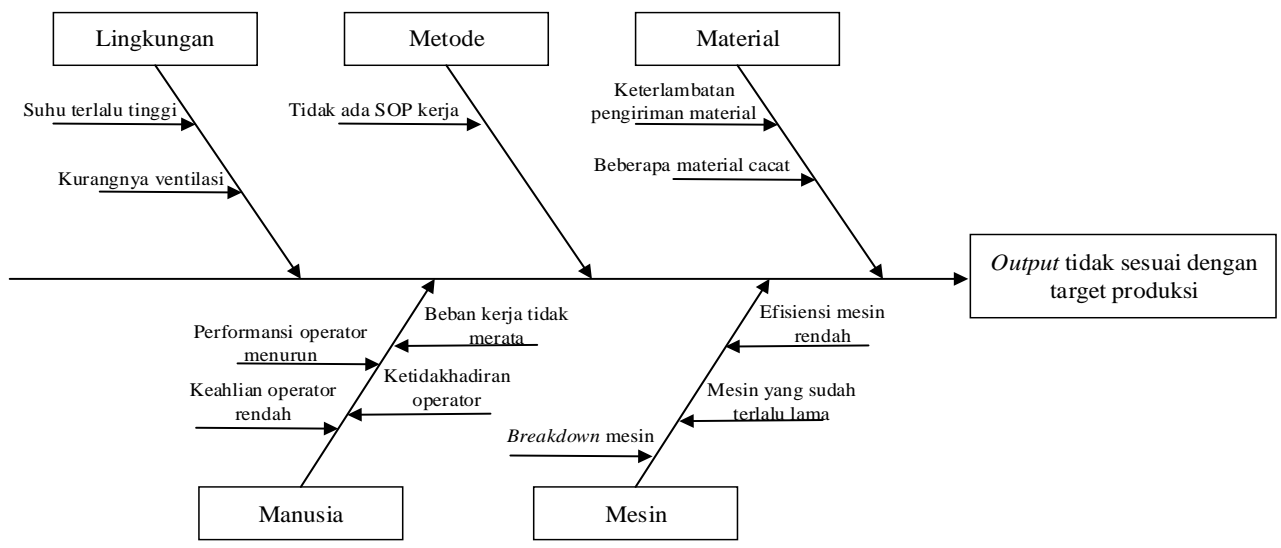

Gambar 2. Fishbone Diagram

Faktor lingkungan mempengaruhi karena suhu lingkungan yang relatif tinggi dan kurangnya ventilasi yang menyebabkan operator tidak nyaman saat melaksanakan proses produksi. Faktor metode mempengaruhi karena tidak adanya standard operation process pada setiap mesin yang menyebabkan banyak terjadi rework dan output tidak sesuai dengan target. Faktor keterlambatan kedatangan material menyebabkan waktu produksi menjadi mundur melebihi jadwal induk produksi. Faktor manusia disebabkan karena performansi operator yang menurun, keahlian operator rendah, beban kerja yang tidak merata, dan ketidak hadiran operator. Faktor mesin disebabkan karena mesin yang terlalu lama, sering terjadi breakdown mesin, dan efisiensi mesin yang tergolong rendah. Dari akar permasalahan tersebut, dapat diketahui bahwa akar permasalahan yang paling mungkin untuk diperbaiki yaitu adanya pembagian beban kerja yang tidak merata pada proses sewing. Sehingga dari permasalahan tersebut dapat diberikan usulan perbaikan dengan menggunakan line balancing pada proses sewing untuk meningkatkan efisiensi lintasan sewing. 
Tabel 3. Elemen Kerja Awal

\begin{tabular}{|c|c|c|c|c|c|}
\hline No & Elemen Kerja & SMV & $\begin{array}{l}\text { Pitch } \\
\text { Time }\end{array}$ & UCL & LCL \\
\hline 1 & Menjahit Paspol & 1,029 & \multirow{24}{*}{0,897} & \multirow{24}{*}{1,166} & \multirow{24}{*}{0,628} \\
\hline 2 & Menjahit Saku & 1,169 & & & \\
\hline 3 & Menjahit Tali & 0,316 & & & \\
\hline 4 & Menjahit karet pada waistban & 0,878 & & & \\
\hline 5 & Menjahit waistban pada celana & 0,994 & & & \\
\hline 6 & Menjahit celana bagian dalam & 1,007 & & & \\
\hline 7 & Menjahit celana bagian luar & 0,757 & & & \\
\hline 8 & Menjahit lipatan bagian depan celana & 0,410 & & & \\
\hline 9 & Menjahit heming bawah & 0,519 & & & \\
\hline 10 & Menjahit belahan bawah & 0,686 & & & \\
\hline 11 & Menjahit label & 0,348 & & & \\
\hline 12 & Mengobras Paspol & 1,196 & & & \\
\hline 13 & Mengobras Saku & 1,139 & & & \\
\hline 14 & Mengobras Tali & 0,398 & & & \\
\hline 15 & Mengobras waistban & 1,025 & & & \\
\hline 16 & Mengobras celana bagian dalam & 1,056 & & & \\
\hline 17 & Mengobras celana bagian luar & 0,991 & & & \\
\hline 18 & Mengobras heming bawah & 1,145 & & & \\
\hline 19 & Assembly paspol dengan celana & 1,185 & & & \\
\hline 20 & Assembly saku dengan celana & 1,070 & & & \\
\hline 21 & Assembly celana bagian kanan dan kiri & 0,983 & & & \\
\hline 22 & Assembly tali dengan waistban & 1,193 & & & \\
\hline 23 & assembly waistban dengan celana & 1,143 & & & \\
\hline & $\begin{array}{c}\text { Average } \\
\end{array}$ & 0,897 & & & \\
\hline
\end{tabular}

Line balancing dilakukan dengan menambah atau mereduksi elemen kerja sesuai dengan mesin yang digunakan. Untuk menambah atau mereduksi elemen kerja dilakukan berdasarkan waktu standar pada produksi apparel yang disebut Standard Minute Value. SMV dihitung dengan mempertimbangkan performansi operator sebesar 79\% dan toleransi sebesar 20\%. Setelah didapatkan SMV setiap elemen kerja, ditentukan waktu rata-rata untuk proses sewing (pitch time). Kemudian dilakukan perhitungan batas atas (upper control limit) dan batas bawah (lower control limit) sebesar 30\% dari pitch time. $30 \%$ didapatkan dari allowance yang masih dalam batas toleransi. Berikut merupakan data SMV, pitch time, UCL, dan LCL dari elemen kerja awal pada tabel 3.

Dari data tersebut belum diketahui elemen kerja yang keluar dari batas UCL dan LCL, maka dibuat grafik mengenai SMV, pitch time, UCL, dan LCL untuk memudahkan memahami elemen kerja yang keluar dari batas UCL dan LCL. Berikut merupakan grafik waktu elemen kerja awal pada gambar 3.

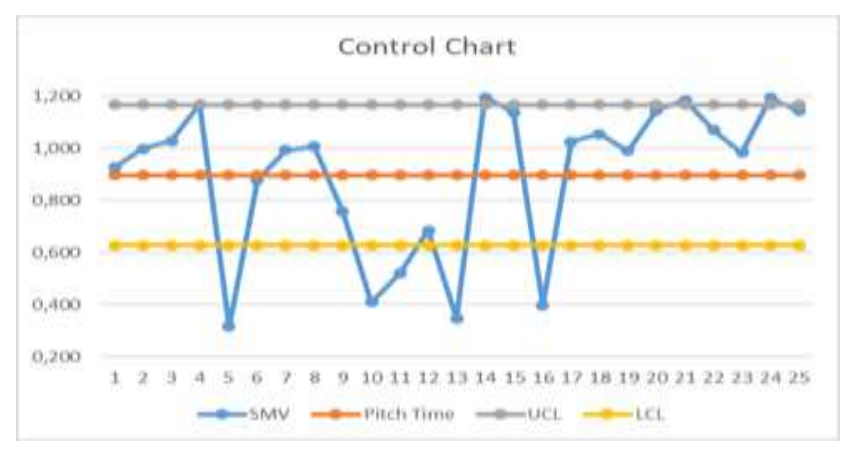

Gambar 3. Grafik Waktu Elemen Kerja Awal

Berdasarkan grafik tersebut terdapat beberapa elemen kerja yang melebihi UCL dan kurang dari LCL, maka dilakukan penyederhanaan dengan menggabungkan beberapa elemen kerja supaya tidak ada waktu dari elemen kerja yang melebihi batas UCL dan LCL.

Pengelompokan elemen kerja usulan sebagaimana disajikan pada tabel 4, dilakukan berdasarkan elemen kerja yang saling berhubungan berdasarkan waktu proses sehingga perbedaan waktu antara elemen kerja satu dengan yang lainnya tidak terlalu jauh. 
Tabel 4. Elemen Kerja Usulan

\begin{tabular}{|r|l|c|}
\hline No & \multicolumn{1}{|c|}{ Work Elemen } & SMV \\
\hline 1 & Menjahit Paspol & 1,029 \\
\hline 2 & Menjahit Saku + Tali & 0,900 \\
\hline 3 & Menjahit Saku + Lipatan bagian depan celana & 0,995 \\
\hline 4 & Menjahit karet pada waistban & 0,878 \\
\hline 5 & Menjahit waistban pada celana & 0,994 \\
\hline 6 & Menjahit celana bagian dalam & 1,007 \\
\hline 7 & Menjahit celana bagian luar & 0,757 \\
\hline 8 & Menjahit belahan bawah & 0,686 \\
\hline 9 & Mengobras Paspol + Tali & 0,797 \\
\hline 10 & Mengobras Paspol + Tali & 0,797 \\
\hline 11 & Mengobras Saku & 1,139 \\
\hline 12 & Mengobras waistban & 1,025 \\
\hline 13 & Mengobras celana bagian dalam & 1,056 \\
\hline 14 & Mengobras celana bagian luar & 0,991 \\
\hline 15 & Mengobras heming bawah & 1,145 \\
\hline 16 & Assembly paspol dengan celana + heming bawah & 1,112 \\
\hline 17 & Assembly paspol dengan celana + label & 0,940 \\
\hline 18 & Assembly saku dengan celana & 1,070 \\
\hline 19 & Assembly celana bagian kanan dan kiri + tali dengan waistban & 1,088 \\
\hline 20 & Assembly celana bagian kanan dan kiri + tali dengan waistban & 1,088 \\
\hline 21 & assembly waistban dengan celana & 1,143 \\
\hline
\end{tabular}

Dari data tersebut seluruh waktu dari elemen kerja sudah masuk batas UCL dan LCL, kemudian dibuat grafik mengenai SMV, pitch time, UCL, dan LCL untuk memastikan tidak ada waktu dari elemen kerja yang keluar batas UCL dan LCL. Gambar 4, merupakan grafik waktu elemen kerja susulan.

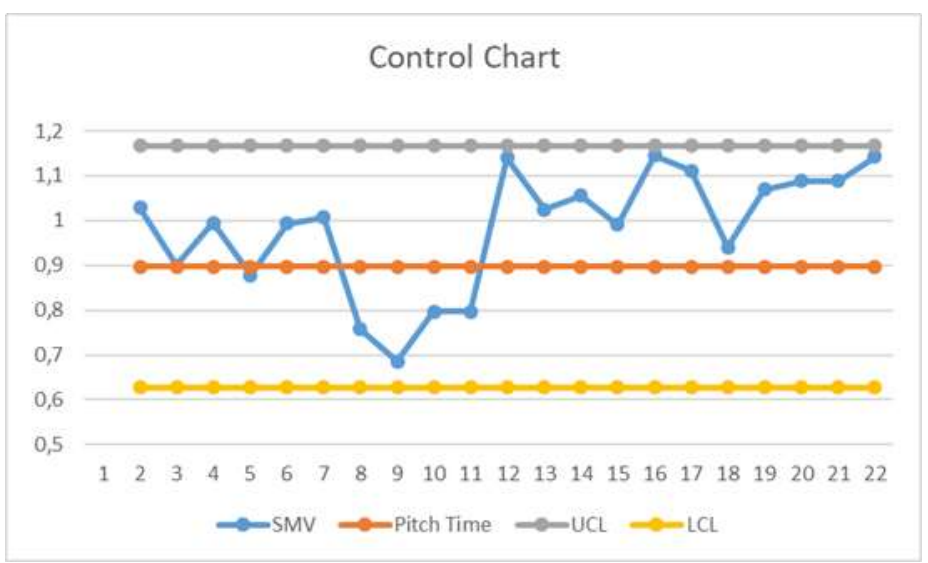

Gambar 4. Grafik Waktu Elemen Kerja Usulan

Berdasarkan grafik tersebut sudah tidak ada elemen kerja yang melebihi batas LCL sebesar 0,628 dan UCL sebesar 1,166. Setelah dilakukan penyesuaian mengenai elemen kerja, kemudian dilakukan perhitungan output berdasarkan elemen kerja yang telah disesuaikan. Perhitungan output terdiri dari output awal dan output usulan. Output awal ditentukan berdasarkan output yang dihasilkan pada perusahaan sedangkan ouput usulan ditentukan dengan rumus :

Output/Hour $=($ Total standard time $) /$ SMV

Tabel 5 menyajikan data output awal. 
Tabel 5. Output Awal

\begin{tabular}{|c|l|c|c|}
\hline No & \multicolumn{1}{|c|}{ Elemen Kerja } & $\begin{array}{c}\text { Output/Jam } \\
\text { (Aktual) }\end{array}$ & $\begin{array}{c}\text { Output } \\
\text { /Hari }\end{array}$ \\
\hline 1 & Menjahit Paspol & 25 & 200 \\
\hline 2 & Menjahit Saku & 30 & 240 \\
\hline 3 & Menjahit Tali & 35 & 280 \\
\hline 4 & Menjahit karet pada waistban & 25 & 200 \\
\hline 5 & Menjahit waistban pada celana & 25 & 200 \\
\hline 6 & Menjahit celana bagian dalam & 25 & 200 \\
\hline 7 & Menjahit celana bagian luar & 25 & 200 \\
\hline 8 & Menjahit lipatan bagian depan celana & 30 & 240 \\
\hline 9 & Menjahit heming bawah & 25 & 200 \\
\hline 10 & Menjahit belahan bawah & 25 & 200 \\
\hline 11 & Menjahit label & 40 & 320 \\
\hline 12 & Mengobras Paspol & 25 & 200 \\
\hline 13 & Mengobras Saku & 25 & 200 \\
\hline 14 & Mengobras Tali & 30 & 240 \\
\hline 15 & Mengobras waistban & 20 & 160 \\
\hline 16 & Mengobras celana bagian dalam & 20 & 160 \\
\hline 17 & Mengobras celana bagian luar & 15 & 120 \\
\hline 18 & Mengobras heming bawah & 15 & 120 \\
\hline 19 & Assembly paspol dengan celana & 15 & 120 \\
\hline 20 & Assembly saku dengan celana & 20 & 160 \\
\hline 21 & Assembly celana bagian kanan dan kiri & 25 & 200 \\
\hline 22 & Assembly tali dengan waistban & 30 & 240 \\
\hline 23 & assembly waistban dengan celana & 25 & 200 \\
\hline & & & \\
\hline
\end{tabular}

Output dihitung setiap elemen pekerjaan didasarkan pada metode SMV untuk mengetahui perbedaan waktu pengukuran elemen kerja antara satu dengan yang lain. Berdasarkan data aktual perusahaan didapatkan output rata-rata per hari 200 sehingga tidak mencapai target, oleh karena itu dilakukan perhitungan pada output usulan berdasarkan elemen kerja yang telah disesuaikan dengan waktu kerja setiap elemen.

Berdasarkan rumus diatas didapatkan output usulan dari setiap elemen kerja sebagaimana disajikan pada tabel 6.

Tabel 6. Output Usulan

\begin{tabular}{|r|l|c|c|}
\hline \multicolumn{1}{|c|}{ No Work Elemen } & \multicolumn{1}{|c|}{ Output/Hour } & Output/Day \\
\hline 1 & Menjahit Paspol & 58 & 464 \\
\hline 2 & Menjahit Saku + Tali & 66 & 528 \\
\hline 3 & Menjahit Saku + Lipatan bagian depan celana & 60 & 480 \\
\hline 4 & Menjahit karet pada waistban & 68 & 544 \\
\hline 5 & Menjahit waistban pada celana & 60 & 480 \\
\hline 6 & Menjahit celana bagian dalam & 59 & 472 \\
\hline 7 & Menjahit celana bagian luar & 79 & 632 \\
\hline 8 & Menjahit belahan bawah & 87 & 696 \\
\hline 9 & Mengobras Paspol + Tali & 75 & 600 \\
\hline 10 & Mengobras Paspol + Tali & 75 & 600 \\
\hline 11 & Mengobras Saku & 52 & 416 \\
\hline 12 & Mengobras waistban & 58 & 464 \\
\hline 13 & Mengobras celana bagian dalam & 56 & 448 \\
\hline 14 & Mengobras celana bagian luar & 60 & 480 \\
\hline 15 & Mengobras heming bawah & 52 & 416 \\
\hline 16 & Assembly paspol dengan celana + heming bawah & 53 & 424 \\
\hline 17 & Assembly paspol dengan celana + label & 63 & 504 \\
\hline 18 & Assembly saku dengan celana & 56 & 448 \\
\hline 19 & Assembly celana bagian kanan dan kiri + tali dengan waistban & 55 & 440 \\
\hline 20 & Assembly celana bagian kanan dan kiri + tali dengan waistban & 55 & 440 \\
\hline 21 & assembly waistban dengan celana & 52 & 416 \\
\hline
\end{tabular}


Dari perhitungan output awal dan usulan diketahui dengan menggunakan metode line balancing dapat meningkatkan output pada lintasan sewing secara signifikan. Setelah dilakukan perhitungan output usulan kemudian menentukan balance efficiency yang merupakan efisiensi keseimbangan lini produksi. Balance efficiency terdiri dari balance efficiency awal dan usulan. Perhitungan balance efficiency menggunakan rumus (2).

Balance Efficiency $=($ Minimum Output $) /($ Average output $)$

Tabel 7.Balance Efficiency Awal

\begin{tabular}{|c|c|c|c|c|}
\hline No & Elemen Kerja & \begin{tabular}{|c|} 
Min \\
Output/Hou
\end{tabular} & $\begin{array}{c}\text { Avg } \\
\text { Output/Hour }\end{array}$ & $\begin{array}{c}\text { Balance } \\
\text { Efficiency }\end{array}$ \\
\hline 1 & Menjahit Paspol & \multirow{23}{*}{15} & \multirow{23}{*}{25} & \multirow{23}{*}{$60 \%$} \\
\hline 2 & Menjahit Saku & & & \\
\hline 3 & Menjahit Tali & & & \\
\hline 4 & Menjahit karet pada waistban & & & \\
\hline 5 & Menjahit waistban pada celana & & & \\
\hline 6 & Menjahit celana bagian dalam & & & \\
\hline 7 & Menjahit celana bagian luar & & & \\
\hline 8 & Menjahit lipatan bagian depan celana & & & \\
\hline 9 & Menjahit heming bawah & & & \\
\hline 10 & Menjahit belahan bawah & & & \\
\hline 11 & Menjahit label & & & \\
\hline 12 & Mengobras Paspol & & & \\
\hline 13 & Mengobras Saku & & & \\
\hline 14 & Mengobras Tali & & & \\
\hline 15 & Mengobras waistban & & & \\
\hline 16 & Mengobras celana bagian dalam & & & \\
\hline 17 & Mengobras celana bagian luar & & & \\
\hline 18 & Mengobras heming bawah & & & \\
\hline 19 & Assembly paspol dengan celana & & & \\
\hline 20 & Assembly saku dengan celana & & & \\
\hline 21 & Assembly celana bagian kanan dan kiri & & & \\
\hline 22 & Assembly tali dengan waistban & & & \\
\hline 23 & assembly waistban dengan celana & & & \\
\hline
\end{tabular}

Berdasarkan elemen kerja awal didapatkan balance efficiency sebesar 60\% yang menunjukkan bahwa efisiensi keseimbangan lintasan sewing masih rendah, sehingga dilakukan perbaikan dengan menggabungkan beberapa elemen kerja berdasarkan pitch time, UCL, dan LCL supaya dapat meningkatkan balance efficiency sehingga produk yang dihasilkan dapat mencapai target produksi baik untuk setiap jam atau setiap harinya. Tabel 8 adalah balance efficiency usulan berdasarkan elemen kerja yang sudah disesuaikan dengan metode line balancing.

Tabel 8. Balance Efficiency Usulan

\begin{tabular}{|c|c|c|c|c|}
\hline No & Work Elemen & Min Output/Hour & Avg Output/Hour & $\begin{array}{c}\text { Balance } \\
\text { Efficiency }\end{array}$ \\
\hline 1 & Menjahit Paspol & \multirow{21}{*}{52} & \multirow{21}{*}{61} & \multirow{21}{*}{$85 \%$} \\
\hline 2 & Menjahit Saku + Tali & & & \\
\hline 3 & Menjahit Saku + Lipatan bagian depan celana & & & \\
\hline 4 & Menjahit karet pada waistban & & & \\
\hline 5 & Menjahit waistban pada celana & & & \\
\hline 6 & Menjahit celana bagian dalam & & & \\
\hline 7 & Menjahit celana bagian luar & & & \\
\hline 8 & Menjahit belahan bawah & & & \\
\hline 9 & Mengobras Paspol + Tali & & & \\
\hline 10 & Mengobras Paspol + Tali & & & \\
\hline 11 & Mengobras Saku & & & \\
\hline 12 & Mengobras waistban & & & \\
\hline 13 & Mengobras celana bagian dalam & & & \\
\hline 14 & Mengobras celana bagian luar & & & \\
\hline 15 & Mengobras heming bawah & & & \\
\hline 16 & Assembly paspol dengan celana + heming bawah & & & \\
\hline 17 & Assembly paspol dengan celana + label & & & \\
\hline 18 & Assembly saku dengan celana & & & \\
\hline 19 & Assembly celana bagian kanan dan kiri + tali dengan waistban & & & \\
\hline 20 & Assembly celana bagian kanan dan kiri + tali dengan waistban & & & \\
\hline 21 & assembly waistban dengan celana & & & \\
\hline
\end{tabular}


Dari perhitungan balance efficiency awal dan usulan diketahui dengan menggunakan metode line balancing dapat meningkatkan balance efficiency pada lintasan sewing sebesar $25 \%$ sehingga aliran proses produksi dapat berjalan dengan lancar dan meminimalisir terjadinya bottleneck.

\section{Simpulan}

Berdasarkan dari proses observasi dan analisis yang telah dilakukan pada penelitian ini dapat disimpulkan bahwa bottleneck terjadi pada lintasan produksi sewing dengan efisiensi keseimbangan lintasan awal sebesar $60 \%$ yang menyebabkan perusahaan tidak dapat mencapai target produksinya baik setiap jam maupun setiap harinya. Oleh karena itu dilakukan perbaikan dengan menggunakan metode line balancing dengan melakukan penyederhanaan pada elemen kerja dari 23 elemen kerja menjadi 21 elemen kerja, sehingga dapat meningkatkan balance efficiency menjadi 85\% dan meningkatkan output produksi dari 200 unit/hari menjadi 495 unit/hari.

\section{Daftar Pustaka}

Babu, V Ramesh. (2012). Industrial Engineering in Apparel Production. Woodhead Publishing, India.

Bedworth, D. \& Bailey, J. (1982). Integrated production control system. John Wiley and sons, New York, USA.

Groover, P Mikell. (2002). Automation Production Systems and Computer-Integrated Manufacturing. Pearson International, Beijing, China.

Indrawan, Yayan \& Hariastuti, Ni Luh Putu. (2013). Minimalisasi Bottleneck Proses Produksi dengan Menggunakan Metode Line Balancing. Teknik Industri, Institut Teknologi Adhi Tama, Surabaya.

Jaganathan V. P. (2014). Line balancing using largest candidate rule algorithm in a garment industry: a case study. International Journal of Lean Thinking.

Kesempatan Besar, Industri Garmen \& Tekstil di Indonesia Butuh Banyak Tenaga Kerja!: Robs Jobs Media. https://media.robsjobs.co/kesempatan-besar-industri-garmen-tekstil-di indonesia-butuh-banyaktenaga-kerja/ (Diakses 19 November 2018).

Purnomo, Hari. (2004). Pengantar Teknik Industri. Graha Ilmu Indonesia, Yogyakarta, Indonesia.

Wignyosoebroto, S. (1995). Ergonomi, Studi Gerak dan Waktu. PT. Guna Widya, Jakarta, Indonesia.

Nurhasanah Nunung dan Simanjutak J P. (2012). Pengukuran Produktivitas Alur Produksi Menggunakan Metode Line Balancing di PD Sandang Jaya. INASEA, Vol. 13 No.2. 
